УДК 821.161 .1

\title{
М.И. Крюкова
}

\section{«ЖИВЫЕ» КУКЛЫ И «ОКАМЕНЕВШИЕ» ГЕРОИ БОРИСА ЮЛЬСКОГО}

В статье анализируется мотив оживающих манекенов и кукол в творчестве Б.М. Юльского - писателя дальневосточной эмиграции. В центре внимания оказываются два рассказа писателя - «Бородатый валет» и «Прекрасная королевна». В начале XX в. мотив куклы становится сюжетообразующим и очень популярным в литературе, встречается как в творчестве классиков, так и беллетристов. В работе отмечено влияние на произведения Юльского творчества Гофмана и Пушкина, а также обнаружены интермедиальные связи с текстами Набокова и Грина. Кроме того, в рассказах Юльского важен мотив улыбающейся карты. Несмотря на то, что писатель жил и работал в Китае и в Тоогэне (в таежной атмосфере), рассмотренные тексты переносят читателя на Запад, в пространство, где неживые героини вмешиваются в сюжет и концентрируют его вокруг себя. Сущность героев Юльского статична и бездушна, поэтому они не могут оживить «искусственную» душу кукол.

Ключевые слова: Б.М. Юльский, мотив куклы, оживающие манекены, куклы и карты, статика, динамика.

DOI: $10.35634 / 2412-9534-2020-30-3-520-528$

Исследователи творчества Бориса Михайловича Юльского (1912 - 1950?) отмечают, что рассказы писателя дальневосточной эмиграции впитали ориентальную и региональную культуру и мифологию Китая (Е.О. Кириллова, А.А. Забияко). Действительно, писатель с раннего детства жил в Харбине, активно участвовал в политической и культурной жизни города. Е.О. Кириллова рассматривает ориентальную мифологию в творчестве Юльского, этнокультурную тему, маньчжурский колорит в его рассказах, анализирует типы героев, а также мотивы сумасшествия и смерти, ухода от реальности, отшельничества и др. [10]. А.А. Забияко посвятила несколько статей художественной этнографии в литературе дальневосточной эмиграции, в том числе и в творчестве Юльского [8]. Опубликованы также отдельные статьи по прозе писателя: Ю.В. Степанюк исследовала «белую мазурку» [15], Т.Ф. Ускова сопоставила сюжет о блудном сыне в рассказах Набокова и Юльского [17]. Юльского рассматривают и как последователя традиций Джека Лондона, Фенимора Купера и Джеймса Кервуда (А.А. Забияко).

Кроме того, в некоторых рассказах писателя отчетливо видно влияние творчества Гофмана и Пушкина (например, использование мотива оживающей куклы и карточного изображения). Валерий Перелешин вспоминал о Юльском как о поразительно начитанном человеке из интеллигентной семьи, отлично знавшем русских классиков [10].

В начале XX в. мотив куклы/манекена, фрагментированного человеческого тела, занимавший умы художников, писателей и теоретиков искусства, становится чрезвычайно актуальным. Эта тема приходит от романтиков, которые осознавали значение механизмов, похожих на людей, но не являющихся ими. Э.Т.А. Гофман боялся того, что человеческая личность обесценивается, утрачивает значимость и становится сравнимой с куклой-марионеткой, поддающейся любому желанию ее кукловода. Н.Я. Берковский, анализируя творчество Гофмана, размышлял о природе романтического двойничества: «Двойник - величайшая обида, какая может быть нанесена человеческой личности. Личность в качестве личности прекращается. В живом теряется жизнь и душа. Двойничество у Гофмана рождает образ куклы. Этот принцип идет и вглубь персонажа. Психология его до чрезвычайности упрощается: она состоит из элементов, связанных, как колесики в механизме. Гофман создает двухмерный мир, населенный двухмерными существами, с душами, которые наделены чуть ли не геометрическими формами» [3. С. 446]. Статичность кукольного персонажа преодолевается, и он оживает. «В новелле “Щелкунчик и мышиный король” Гофман отождествляет живое существо с куклой, так что трудно различить, где кончается одно и начинается

\footnotetext{
${ }^{1}$ Работа выполнена при поддержке гранта РНФ № 19-18-00127 «Сибирь и Дальний Восток первой половины ХХ века как пространство литературного трансфера».
} 
другое. У живой принцессы отвинчиваются руки и ноги и затем водворяют их на место, а куклу вылечивают от ран. Кукла Олимпия в "Песочном человеке" вращается в высшем обществе, как равная среди равных. Куклы и автоматы - это мерило "обездухотворенности" и механистичности своекорыстного прозаического мира» [11. С. 66].

Через мотив оживающих кукол/манекенов и карт обнаруживаются типологические переклички в рассказах Юльского с произведениями В. Набокова и А. Грина, когда игрушки или изображения обретают человеческие черты, а человек, напротив, застывает, «окаменевает», и героев можно охарактеризовать с точки зрения статичной и динамичной природы их души. Мотив куклы/манекена оказывается значимым: в какой-то мере, это рецепция романтической традиции, когда наделенные душой герои борются с механистическим миром, а у Грина это вариация на тему оживающей скульптуры, где кукла/манекен становится воплощением выхода из статики в живой динамичный мир.

Мотив оживающей куклы (манекена) прослеживается в рассказах Юльского «Прекрасная королевна» (1933) и «Бородатый валет» (1938). И хотя восковые героини по сюжету не приходят в движение, они, тем не менее, метафорически нарушают естественный баланс неподвижности статичных персонажей в произведении, влияя тем самым на ход событий.

В начале рассказа «Бородатый валет» перед читателем предстают два героя: Андрей Иванович и его возлюбленная - девушка из магазина. Немного позже читатель узнает, что она манекен в витрине. Но автор привносит в статичный образ динамику, описывая куклу так: «Ее поза полна живой грации. Она, кажется, только остановившейся на миг и застывшей в изумительно изящном повороте головы» [21. С. 360]. Красота ее сравнивается с Беатриче, музой и тайной возлюбленной Данте, что означает поистине идеальную любовь.

Андрей Иванович называет любимую Элеонорой, объясняя свой выбор именем героини романа Вальтера Скотта. Однако кукла у Юльского похожа и на красавицу одноименного рассказа Э. По. Элеонора Э. По отвечает взаимностью герою, но умирает, а ее возлюбленный в финале благополучно женится (на что отзывается сюжет рассказа Юльского).

Примечательно, что, питая чувства к восковой кукле, Андрей Иванович и сам представлен достаточно статичным персонажем. Жизнь его однообразна, проста и спокойна. Манекен в витрине - единственное яркое пятно в его существовании. Другая его возлюбленная (которую он до финала возлюбленной не осознает) - соседка Матильда, гадалка и хиромантка. На двери ее комнаты нарисованы три гадальных карты с изображением гроба, медведя и кольца. Очевидно, три карты символизируют трех персонажей рассказа. Гроб - как неживой предмет ассоциируется с Элеонорой, находящейся в неподвижном состоянии в витрине магазина, в стеклянном заточении (ср. со спящей царевной Пушкина). Медведь это Андрей Иванович, большой и бородатый. Кольцо остается для Матильды, с которой обвенчается герой в конце рассказа.

Извивы кольца будто напоминают змеиные волосы Медузы Горгоны, на которую немного похожа героиня. Матильда описана красавицей со «жгучими глазами и завитком черных волос» [21. С. 362], она носит шуршащие шелковые платья. Тем не менее, она не может взглядом погубить (то есть очаровать, заполучить для себя) Андрея Ивановича, так как он уже, подобно своей истинной застывшей возлюбленной, словно сделан из камня.

Название рассказа связано с картой, олицетворяющей героя, а весь текст будто становится ожившим экфрасисом, повествующим об истории карточного изображения. Матильда гадает Андрею Ивановичу, называя его трефовым валетом. Так возникает другая карточная триада: валет и две дамы (Элеонора и Матильда).

Вспоминая знаменитый роман Набокова 1928 г. «Король, дама, валет» и проводя аналогию с текстом «восточного» эмигранта, мы обнаруживаем, что в рассказе Юльского «не хватает короля. «В основе структуры романа Набокова - треугольник, определяющий “геометрию текста". Процесс "обмертвления" главных действующих лиц сопровождается нарастанием механистичности в их облике и человеческих отношениях, что определяет “одну из магистральных линий художественного сознания XX века”, поднимающего "проблему кукольности человеческих отношений, основанных на взаимозависимости "марионетка / кукловод”» [4. С. 164]. Такой марионеткой в руках Марты (карточная «дама» в романе) стано- 
вится Франц («валет»). Элеонора Юльского будто тоже порабощает разум Андрея Ивановича. И хотя герой боится, что кто-то может узнать, что он «играет в куклы» [13. С. 361], он не замечает, как становится полностью зависимым от прекрасного манекена.

Л.Ю. Стрельникова пишет, что Набоков «неоднократно сравнивает Франца с неодушевленным существом - он и “восковая фигура", и “веселая кукла", и “мертвая кукла". Марта изображается в окружении красивых кукольных вещей, поэтому сама воспринимается как красивая вещь, “светлый призрак” из зазеркалья, ее внешность ничем не одухотворена, она напоминает хорошо сделанную куклу (“бархатно-белая кожа", “неподвижные, редко мигавшие глаза”...)» [16. С. 360]. Так и у Юльского герой сам становится безвольной куклой манекена. Он не замечает живую Матильду, всецело поглощенный своими чувствами к Элеоноре. В описании Юльским манекена чувствуется желание преодолеть статичную природу: «Лицо ее не маска куклы» [21. С. 360]. Глядя на Элеонору, прохожие сокрушаются, что «это лицо не живое, не настоящее человеческое лицо» [21. С. 360].

Контраст динамики и статики при описании персонажей отсылает нас и к новелле Грина «Серый автомобиль». Герой новеллы Сидней пылко влюблен в девушку, которая, как обнаружит в финале сошедший с ума герой, - сбежавший из магазина манекен. Сидней это чувствует, он замечает безучастное выражение голоса Корриды, пустую улыбку и бледное, как у восковой фигуры, лицо. В романе Набокова «Камера обскура» искусствовед Кречмар подобным образом видит героиню: «Прелестное лицо Магды портило бессмысленное выражение, ничего оно не выражало, как у бездушной куклы немого кино» [13. С. 329]. Вся культура XX в. решает проблему противостояния живого и механистичного, непосредственности и принужденности (выражаемой даже внешне - в позах, мимике). Для Набокова, как и для Грина, эта двойственность очень важна, она неоднократно проявляется в сюжетах его романов.

В новелле Грина девушка, в которую влюблен Сидней, ведет, казалось бы, обычный образ жизни любит красивые вещи, наряжаться, развлекаться, - герою этого недостаточно. Сидней хочет ее оживить, вдохнуть в нее настоящую живительную силу, но единственным выходом для подобного преображения оказывается смерть. «Я постиг тайну вашего механизма, - говорит Корриде Сидней. - Он уподобился внешности человеческой жизни силой всех механизмов, гремящих вокруг нас. Но стать женщиной, стать истинно живым существом вы можете только после уничтожения» [5. С. 341]. Сидней чувствует себя настоящим Пигмалионом, который готов оживить свою Галатею. Настоящая любовь всегда требует от любящего готовности пробудить предмет своей любви, но метафорическое значение этого понятия Грин переводит в буквальное. Сидней убежден, что только смерть может преобразить восковую куклу и сделать ее настоящей девушкой.

Коррида Грина напоминает героиню из рассказа Юльского «Закон жизни» (1935) Валерию Павловну: «ее мраморное лицо, светло-голубые глаза и гладкие золотистые волосы - все это дышало холодной, неживой красотой. И в своих отливающих блеском шелка туалетах она казалась гибкой и холодной, как змея» [21. С. 282]. Ее внешность притягивает Маркова, но он несчастлив с ней. Валерия, как Медуза Горгона (у нее змеиная красота), чуть не доводит героя до самоубийства. Марков спасается бегством в таежный поселок, где находит счастье с непосредственной и простой девушкой. Однако Валерия не исчезает из сердца Маркова бесследно, он держит ее фотографию на столе, сказав жене, будто это умершая сестра. Фотография, как и манекен, является неживым изображением персонажа, тем не менее, она способна вызывать чувства и влиять на поступки героев. В этом состоит особенная сила существования кукол, их мнимая жизнь. Ю.М. Лотман в статье «Куклы в системе культуры» рассуждает о биполярной семантике кукол, которые могут характеризовать «антитезы живого / неживого, оживающего / застывающего, одухотворенного / механического, мнимой жизни / жизни подлинной» [12. С. 380].

Не случайна и гибель манекена в рассказе Юльского. Манекен мог переродиться в героиню, но только не предназначенную для Андрея Ивановича: герой любил именно куклу, он не хотел преображения и оживления, он тяготел к статике. Именно этим привлекала его Элеонора.

В рассказе Юльского, как и в новелле Грина, важен мотив улыбающейся карты. Матильда при гадании ассоциирует его с валетом: «Валет щурился, и Андрею Ивановичу показалось, что он втихомолку улыбается. Еще раз покосившись на карты, Андрей Иванович... незаметно перевернул ухмыляющегося валета лицом вниз» [21. С. 365]. 
В новелле Грина Сидней выигрывает карточную партию благодаря карте с «улыбающимся» чертом, джокером. Его партнер по игре умирает. Тем самым мотив оживающей карты оказывается связанным с гибелью героя (у Юльского Андрей Иванович чудом остается в живых, избежав несчастного случая на дороге). Ожившая карта, как и в «Пиковой даме» Пушкина и «Сером автомобиле» Грина, предвещает печальные изменения в судьбе героя. И действительно, сначала Андрея Ивановича ждет утрата своей возлюбленной, потом он попадает в больницу.

Возможно, если бы герой любил легенду о Пигмалионе и Галатее, у Элеоноры появилась бы возможность сойти в живую жизнь со своего пьедестала. Но этого не произошло, поскольку герой не был ни художником-творцом, ни человеком высокой силы духа, способным заронить живительную искру в изваяние. Он сам существовал как картинка - бородатый валет.

Когда Элеонора исчезает - «гибнет», Андрей Иванович испытывает настоящее горе, как от потери живой возлюбленной. Приказчик отдела объясняет, что куклу разбили, так как она была мастиковой. Убитый горем герой не замечает ничего вокруг, даже когда выходит на дорогу. «Ему наперерез мчался слоновой рысью толстый автобус и трубно кричал» [21. С. 367]. Несмотря на то, что он отступает на два шага, его все равно сбивает «оживший» и превратившийся в слона автобус.

Исследователи отмечают, что в творчестве Юльского чувствуется влияние китайской культуры и мифологии. Слон в этой культуре символизирует мощь, силу и энергию. Значение жизненной энергии имеет и голубой цвет. Возможно, несчастный случай на дороге, наоборот, был символом перерождения героя, после которого глаза Матильды все-таки прожигают окаменевшее сердце Андрея Ивановича.

В новелле «Серый автомобиль» Сидней пытался сделать так, чтобы его восковая возлюбленная прошла перерождение. Его преследует серый автомобиль и однажды тоже чуть не сбивает его. У Грина страх перед машинами символизирует протест против механизированности мира, порабощения его машинами. Для персонажа новеллы автомобили, проезжающие мимо, угрожали ему искалечением или смертью. При этом героя удивляет их «до странности живой вид, даже когда он стоял молча, подстерегая» [5. С. 318]. Автомобили близки манекенам с точки зрения их механистичности и искусственности. Для Сиднея Коррида и оживший/обезумевший автомобиль оказываются близки, так как их объединяет «мертвая жизнь». Сам герой хочет спасти и свою возлюбленную, и даже своего врага - автомобиль. Он предполагает, что машина «обладает, кроме движения, неким невыразимым сознанием». Сидней рассуждает о том, что у автомобиля есть дом, на стенах которого висят портреты - фотографии моделей: «У него есть даже любовницы, это леди, обращающие с окон модных магазинов улыбку своих восковых лиц» » [5. С. 330]. Речь идет о манекенах, оживших манекенах, способных улыбаться и даже любить. «Серый автомобиль» Грина - демонический двойник механической куклы, который не дает герою оживить мертвую душу Корриды.

А.В. Громова отмечает: «в “Сером автомобиле” находим полемику с идеями авангарда и прозрачные отсылки к первым манифестам европейского футуризма - произведениям его создателя и идеолога Ф.Т. Маринетти... Ф.Т. Маринетти выступил против старого искусства, воспевавшего “задумчивую неподвижность, экстаз и сон”, и провозгласил новое - агрессивное, яростное и беспощадное искусство будущего, рожденное машинной цивилизацией» [7. С. 266].

В конце рассказа Юльского еще раз подчеркивается: к лучшему, что Элеонора не проснулась, и жизнь героя осталась проста. Возможно, потому, что другого счастья он не заслужил. Увидеть чудо в жизни (например, услышать разговор тополей) способен тот, кто «не очерствел в жизненной борьбе, у кого не заглохла душа и сердце не стало мохнатым» [21. С. 371]. Е.Г. Иващенко так характеризует героев произведений Юльского: «Персонажи, за редким исключением, не пытаются переломить ситуацию, не бунтуют, не ищут правду жизни. Для них характерны созерцательная позиция, социальный скепсис, безволие, инертность» [9. С. 117].

С другой стороны, если бы мечта Андрея Ивановича исполнилась, и он смог бы, например, обладать манекеном, не постигла ли бы его участь, подобная героям В.Ф. Одоевского («Сказка о том, как опасно девушкам ходить толпою по Невскому проспекту» и А.П. Каменского («Идеальная жена»). Героиню Одоевского превратили в манекен, и, хотя ее покупает молодой человек, заботится о ней и разговаривает с ней, души их разъединены, так как у нее нет сердца (его вырезал «басурманин»). В конце рас- 
сказа герой выбрасывает куклу в окно. Наскучивает кукла и героям Каменского. Они покупают резиновую куклу, «слегка напоминающую музейную восковую фигуру» в качестве жены, но вскоре ее существование становится бессмысленным, и ее продают.

Пратекстом всех этих произведений, возможно, является новелла Гофмана «Песочный человек», сюжет которой - подмена живой девушки восковой куклой. Натанаэль увидел Олимпию «через стеклянную дверь» [6. С. 90] - будто через витрину восковую куклу, и сразу воспылал к ней чувством. Прежнюю же возлюбленную он называет «бездушным автоматом» [6. С. 95], и выбирает безжизненную куклу Олимпию. У Гофмана всему виной - загадочные очки Коппелиуса, который таким образом ставится хозяином глаз Натанаэля и забирает его душу, и поэтому Натанаэль не замечает «скованности и бездушности», «безжизненного взора, лишенного зрительной силы» [6. С. 101] Олимпии. Неестественная любовь губит Натанаэля: герой сходит с ума и погибает.

Рассматривая мотив оживающей куклы/ манекена, нельзя не вспомнить и повесть А.В. Чаянова «История парикмахерской куклы, или Последняя любовь московского архитектора М.», главный герой которой тоже влюбляется в манекен, стоящий на витрине парикмахерской. Архитектор М. хочет видеть свою возлюбленную живой, поэтому находит оригинал куклы, модель манекена. Но и в этой повести встречается некий симбиоз статичности и одухотворенности героини. Безумное увлечение героя получает некоторое объяснение: «кукла», сделанная по образцу Берты, так притягательна, потому что сама девушка таит в себе черты манекена: «Казалось, будто все, что она говорит и делает, было не настоящим, нарочным, произносимым только из учтивости к собеседнику и мало интересным ей самой. Ее кажущаяся оживленность была холодна, и огромные глаза часто заволакивались тусклым свинцовым блеском. Казалось, что где-то там, вне наблюдения собеседника, у нее была иная жизнь, завлекательная, глубокая своим содержанием» [19. С. 72]. Эти черты сближают ее с Корридой, в которую влюблен герой Грина Сидней.

Таким образом, в начале XX в. мотив куклы, которая хоть и не оживает напрямую, но становится полноценной героиней, был очень популярен и встречался как в творчестве классиков, так и беллетристов.

Данный мотив характерен и для русской поэзии Китая, в частности, для стихотворений поэта младшего поколения восточной ветви эмиграции Н. Щёголева «Витринная кукла» (1932) и «Сирена» (1933). К.В. Абрамова пишет, что «“Сирена”- это экфрасис, лексический строй которого восходит к поэзии пушкинской эпохи (достаточно взглянуть хотя бы на элегическую рифму печально/необычайно, вернее - печально/ необычайной - в варианте Щёголева), кроме того, акмеистические экфрасисы, особенно "Царскосельская статуя" Ахматовой, явно повлияли на "Сирену” (ср. “Поджав незябнущие ноги” у Ахматовой и "Сидит - поджатые колена" у Щёголева). Сюжет стихотворения тоже традиционный и оксюморонный: ожившая статуя, любовь к статуе живого “красивого человека”, мёртвое как живое и живое как мёртвое» [1. С. 139]. Лирический герой в стихотворении, как и Андрей Иванович Юльского, «прикован» (что придает ему статичные черты) к своей «возлюбленной» («Он с ней до сумерек сидит» [20. С. 31]). В стихотворении Щёголева «оцепенелая» героиня все же оживает по ночам, но приходит она не к своему поклоннику, а фавну.

Не могут быть счастливыми и герои стихотворения «Витринная кукла»:

$$
\begin{aligned}
& \text { Фигурка, вы - последняя влюбленность. } \\
& \text { Пусть нездорово, но, по крайней мере, } \\
& \text { Не тронет вас моя испепеленность. } \\
& \text { А звать вас буду Ирмой или Мэри [20. С. 26]. }
\end{aligned}
$$

Герой вслед за Андреем Ивановичем дает манекену имя, пытаясь присвоить ей какое-то качество обычной девушки. И он так же, как и герой Юльского, знает о необычной природе его чувств («пусть нездорово»), но манекен все же остается его «мечтой старинной».

Н.М. Солнцева в монографии «Репутация куклы» рассматривает куклы как прародительниц манекенов: «Сначала появились Пандоры. Потом они расселились в витринах...Пандора была соблазнительна даже для бессмертных. Известно о погибшей в 1736 г. фреске П. Миньяра: Пандора на облаке, окруженная впавшими в восторг богами. Тем более она манок для людей. Памятна теза Гесиода о Пандоре - первой женщине планеты, населенной мужчинами. На ней женился брат Прометея. Она задумана как оболь- 
стительное зло для смертных за украденный огонь... Душа Пандоры лживая, речи обольстительные, она выпустила из сосуда невиданные бедствия, но в поздние времена дамы и стилисты это ей как бы простили, а ее красоту и наряды сделали символом» [14. С. 106].

Во всех рассмотренных нами произведениях влюбленность героя в манекен или куклоподобную героиню заканчивается трагически. Неживой персонаж не способен вести полноценную жизнь, несмотря на то, что так похож на обычных героев. В то же время часто границы между героями разной природы стираются: между ними происходит обмен ролями. Д. Федяй указывает на сходство людей и манекенов: «На многолюдных же улицах прохожий, особенно не склонный к вынужденным контактам, хотя бы и визуальным (смотрят на него - он смотрит на кого-то), порой склонен воспринимать и реальных людей как манекены, которые просто движутся мимо. Этим сберегается личный потенциал внимания и эмоционального реагирования на происходящее. В магазинах одежды витрина призвана способствовать "переодеванию" покупателя в одежду манекена, а если это элитная одежда, переодевание происходит в самом буквальном смысле: покупатель забирает снятый с манекена штучный образец. Различие между манекенами и живыми людьми на какое-то время почти исчезает » [18. С. 181-182].

Об оживающих игрушках написано много сказок, в которых само волшебное пространство благоприятствует метаморфозам кукольных персонажей. Среди писателей особенно популярен этот мотив в произведениях Г.Х. Андерсена: в сказках «Цветы маленькой Иды», «Стойкий оловянный солдатик», «Оле-Лукойе», «Свинопас», «Соловей», «Пастушка и трубочист». Оживает и преображается «Щелкунчик» Гофмана.

А. Бенуа посвятил свои картины игрушкам, нарисовав двенадцать акварельных картин, изображающих игрушки своего детства. На рисунках изображены игрушки, какие были у художника в детстве. Бенуа вспоминает о них с сердечной благодарностью. Этим чувством, а также желанием хотя бы иногда окунаться в детство, и было вызвано то, что художник стал их коллекционировать и посвятил им серию акварелей. В своей книге воспоминаний он написал: «Многие сказки Андерсена принадлежали тоже к моим любимым, но не те, в которых чувствовались какие-то моральные тенденции. Иные из них я и вовсе не ценил... Зато менее осмысленные сказки Андерсена про "Стойкого оловянного солдатика", про “Дорожного товарища", про “Старый дом" и более всего про "Русалочку” принадлежали (да и до сих пор принадлежат) к любимым мной особенно нежной любовью. И во всех них странная смесь печальной драмы с чем-то радужным и чудесным являлась главной основой их трогательности. В “Солдатике” (как в "Гулливере" или в "Щелкунчике" Гофмана) я, кроме того, особенно ценил прелесть всего этого миниатюрного игрушечного мира » [2].

Есть у Юльского еще одна «живая» восковая кукла - «Прекрасная королевна». Название рассказа опять ассоциируется с карточным изображением - королевой. Персонажа, влюбленного в куклу, Юльский, как в «Бородатом валете», называет Андреем. Кукла взглядом очаровывает Андрейку еще в детстве. Размером она почти такая же, как ее шестилетняя хозяйка Ляля, и это будто приравнивает ее к обычной (не восковой) героине рассказа. Андрею могла понравиться Ляля, но взгляд он не может отвести именно от ее игрушки. И Андрею Ивановичу, и Андрейке достаточно лишь любоваться объектом своего обожания: куклы, даже не шелохнувшись, порабощают волю героев, а их душа каменеет, фокусируясь лишь на своей возлюбленной. Получая наказание за свою шалость, Андрей не плачет, так как кажется ему, что перед ним «как живая стояла прекрасная королевна и смотрела на него чисто-голубыми, прозрачными глазами» [21. С. 213].

Кукла в рассказе «Прекрасная королевна» впервые завораживает героя в Рождество. Вторая роковая встреча Андрея с куклой происходит через двенадцать лет, в декабре, когда люди замерзали на улице с елочными игрушками в карманах. У Гофмана Щелкунчик появляется на Рождество, хотя своей непривлекательностью он противопоставлен героям Юльского. Но, несмотря на внешность куклы, Мари добра и нежна к нему, и это превращает его в живого человека.

В произведениях Юльского метаморфоз с неживыми героинями не происходит. «Прекрасная королевна», проведшая двенадцать лет со своей хозяйкой Леночкой, не знает о революции, о том, что мир перевернулся, что закончилась спокойная жизнь. Видимо, любовь героев не такова, чтобы пробудить их душу. Андрей становится одним из солдат-революционеров со звероподобными лицами, громивших «прежнюю» Россию (одного из солдат Юльский описывает так: «мохнатое лицо с оскаленными зубами» 
[21. С. 214]), и однажды Андрей врывается в Леночкин дом, где хранилась кукла. Один из разбойников, найдя куклу, восклицает: «совсем человек» [21. С. 214], тоже замечая ее живые черты. Андрей, увидев куклу, ведет себя как безумный, хватает ее и жадно смотрит в лицо. И, видимо, магия куклы снова действует, так как он забирает куклу с собой, прижимая к себе. Но кукла несет возмездие герою, в него тут же стреляют на улице, и он умирает в снегу, продолжая держать слегка улыбающуюся куклу.

«В Китае фарфоровых праздничных кукол и кукол на шарнирах обозначают двумя иероглифами человек и идол (ren ou), а для марионеток - дерево и идол (mu ou) или человек и черт, призрак» [14. С. 89]. Во всех этих названиях чувствуется негативная коннотация. И в рассказе Юльского ощущается некая чертовщина: сверхъестественная влюбленность героя в куклу, его странное поведение под воздействием ее глаз - превращение в безвольную марионетку.

Рассказы Юльского «Прекрасная королевна» и «Бородатый валет» входят в ряд произведений, ведущим мотивом которых становятся оживающие куклы (манекены). Несмотря на то, что Юльский жил и работал в Китае и в Тоогэне (в тайге), рассмотренные тексты переносят читателя на Запад, в пространство, где неживые героини вмешиваются в сюжет и концентрируют его вокруг себя. Куклы Юльского раскрывают статичную и бездушную сущность героев, которые не могут оживить «искусственную» душу.

\section{СПИСОК ИСТОЧНИКОВ И ЛИТЕРАТУРЫ}

1. Абрамова К.В. Поэтика харбинских и анхайских Стихотворений Николая Щёголева: Рифмы // Гуманитарный вектор . 2019. Т. 14. № 5. С. 136-144.

2. Бенуа А.Н. Мои воспоминания: в 5 кн. Подг. Н. И. Александрова и др. Книга первая. M.: Наyка, 1980. URL: http://az.lib.ru/b/benua_a_n/text_1955_moi_vospomoinaiya_1.shtml

3. Берковский Н.Я. Романтизм в Германии. СПб.: Азбука-классика, 2001.510 с.

4. Владимирова Н.Г., Куприянова Е.С., Мяновская И. Аллюзии и игра в романе Владимира Набокова «Король, дама, валет» // Проблемы исторической поэтики. 2019. Т. 17. № 1. С. 162-177.

5. Грин А.С. Собрание сочинений в 6 томах // Сост. В.Е. Ковский. М.: Правда, 1980. Т. 4. 480 с.

6. Гофман Э.Т.А. Новеллы. М.: Худож. лит., 1983. 399 с.

7. Громова А.В. Полемика с идеями футуризма в рассказе А. Грина «Серый автомобиль». Текст, контекст, интертекст // Сборник научных статей по материалам Международной научной конференции XV Виноградовские чтения. В 3-х томах. Ответственный редактор И.Н. Райкова. 2019. С. 264-272.

8. Забияко А.А. Проза харбинского писателя Бориса Юльского в контексте художественной этнографии дальневосточного зарубежья // Гуманитарные исследования в Восточной Сибири и на Дальнем Востоке. 2015. № 2 (32). C. $91-102$.

9. Иващенко Е.Г. «Утраченные иллюзии» Бориса Юльского» // Сб. научных работ преподавателей и студентов кафедры русской филологии АмГУ. / Под ред. А.А. Забияко, Е.А. Оглезневой. Благовещенск, 2006. С. $105-127$.

10. Кириллова Е.О. Ориентальные темы, образы, мотивы в литературе русского зарубежья Дальнего Востока (Б.М. Юльский, Н.А. Байков, М.В. Щербаков, Е.Е. Яшнов). Владивосток: Дальневост. федерал. ун-т, 2015.276 с.

11. Кобзев Н.А. Роман Александра Грина (проблематика, герой, стиль). Кишинев: «Штиинца», 1983.140 с.

12. Лотман Ю.М. Куклы в системе культуры // Избранные статьи. Т. 1. Таллинн: Александра, 1992. С. $377-380$.

13. Набоков В.В. Лолита. Камера обскура. Томск: Красноярский рабочий, 1991. 448 с.

14. Солнцева Н.М. Репутация куклы. М.: Водолей, 2017. 176 с.

15. Степанюк Ю.В. Роль образа белой мазурки в картине мира одноимённой повести Бориса Юльского // Филологические открытия. 2015. № 3. С. 181-184.

16. Стрельникова Л.Ю. Основные тенденции русской и западноевропейской литературы в контексте мировой культуры: монография. Армавир: РИО АГПА, 2013. 367 с.

17. Ускова Т.Ф. Сюжет о блудном сыне в рассказах в. Набокова «Звонок» и Б. Юльского «Святочный гость» // Память и нарратив сборник. 2012. С. 148-152.

18. Федяй Д. Статуя в эдикуле и манекен в витрине: живое, неживое, оживающее // Исторические, философские, политические и юридические науки, культурология и искусствоведение. Вопросы теории и практики. 2015 . № 7 (57): в 2 ч. Ч. 1. С. 180-183.

19. Чаянов А.В. Московская гофманиада. М.: Тончу, 2006. 350 с.

20. Щёголев Н.А. Победное отчаянье. Собрание сочинений. М.: Водолей, 2014. 352 с.

21. Юльский Б. Зеленый легион: повесть и рассказы. Владивосток: Альманах «Рубеж», 2011.560 с. 
Крюкова Маргарита Ивановна, кандидат филологических наук, младший научный сотрудник ФГБУ «Институт Филологии СО РАН» 630090, Россия, г. Новосибирск, ул. Николаева, 8

E-mail: iamdaisy@mail.ru

\section{M.I. Kryukova \\ BORIS YULSKY'S “LIVING” DOLLS AND “STONE" CHARACTERS}

DOI: $10.35634 / 2412-9534-2020-30-3-520-528$

The article analyzes the motive of living mannequins and dolls in B.M. Yulsky's work, writer of the Far Eastern emigration. In the centre of attention there are two writer's stories - "The Bearded Jack" and "The Fair Queen". At the beginning of the twentieth century, the doll's motive became plot-forming and very popular in literature, it is found both in the works of classics and fiction writers. The influence of Hoffmann and Pushkin's creativity on Yulsky's work is noted in the paper, as well as the intermedia links with Nabokov and Grin's texts are found. In addition, the motive of a smiling card is also important in Yulsky's stories. Despite the fact that the writer lived and worked in China and Toogen (in a taiga atmosphere), the considered texts take the reader to the West, to the space where inanimate characters intervene in the plot and concentrate it around them. The essence of Yulsky's characters is static and soulless, therefore they cannot revive the "artificial" soul of dolls.

Keywords: B.M. Yulsky, doll motive, living mannequins, dolls and cards, statics, dynamics.

\section{REFERENCES}

1. Abramova K.V. Poetika harbinskih i anhajskih Stihotvorenij Nikolaya SHCHyogoleva: Rifmy [The poetics of Nikolay Shchegolev's Harbin and Ankhai poems: Rhymes]. Gumanitarnyj vector [Humanitarian vector]. 2019, v. 14, no. 5 , pp. 136-144. (In Russian).

2. Benua A.N. Moi vospominaniya: v 5 kn. [My memories: in 5 books]. Podg. N.I. Aleksandrova i dr. Kniga pervaya [Prep. N.I. Alexandrova and others. The first book]. Moscow, Nauka, 1980. URL: http://az.lib.ru/b/benua_a_n/ text_1955 moi_vospomoinaiya_1.shtml. (In Russian).

3. Berkovskij N.Ya. Romantizm v Germanii [Romanticism in Germany]. St. Petesburg, Azbuka-klassika, 2001, 510 p. (In Russian).

4. Vladimirova N.G., Kupriyanova E.S., Myanovskaya I. Allyuzii i igra v romane Vladimira Nabokova "Korol', dama, valet" [Allusions and game in Vladimir Nabokov's novel "King, Queen, Jack"]. Problemy istoricheskoj poetiki [Problems of historical poetics]. 2019, v. 17, no. 1, pp. 162-177. (In Russian).

5. Grin A.S. Sobranie sochinenij v 6 tomah [Collected works in 6 volumes]. Sost. V.E. Kovskij [V.E. Kovsky comp.]. Moscow, Pravda, 1980, v.4. 480 p. (In Russian).

6. Gofman E.T.A. Novelly [Short stories]. Moscow, Hudozh. lit., 1983, 399 p. (In Russian).

7. Gromova A.V. Polemika s ideyami futurizma v rasskaze A. Grina "Seryj avtomobil"'. Tekst, kontekst, intertekst [The polemic with the ideas of futurism in A. Grin's story "Grey Car". Text, context, intertext]. Sbornik nauchnyh statej po materialam Mezhdunarodnoj nauchnoj konferencii XV Vinogradovskie chteniya. V 3-h tomah. Otvetstvennyj redaktor I.N. Rajkova [Collection of scientific articles on the materials of the International scientific conference of the XV Vinogradov readings. In 3 volumes. Executive Editor I.N. Raikova.]. 2019, pp. 264-272. (In Russian).

8. Zabiyako A.A. Proza harbinskogo pisatelya Borisa Yul'skogo v kontekste hudozhestvennoj etnografii dal'nevostochnogo zarubezh'ya [Harbin writer Boris Yulsky's prose in the context of artistic ethnography of the Far Eastern countries]. Gumanitarnye issledovaniya v Vostochnoj Sibiri i na Dal'nem Vostoke [Humanitarian research in Eastern Siberia and the Far East]. 2015, no. 2 (32), pp. 91-102. (In Russian).

9. Ivashchenko E.G. «Utrachennye illyuzii» Borisa Yul'skogo [Boris Yulsky's "Lost Illusions"]. Sbornik nauchnyh rabot prepodavatelej i studentov kafedry russkoj filologii AmGU. Pod redakciej A.A. Zabiyako, E.A. Ogleznevoj [A collection of scientific papers by teachers and students of the Department of Russian Philology of AmSU. Edited by A.A. Zabiyako, E.A. Oglzneva]. Blagoveshchensk, 2006, pp. 105-127. (In Russian).

10. Kirillova E.O. Oriental'nye temy, obrazy, motivy v literature russkogo zarubezh'ya Dal'nego Vostoka (B.M. Yul'skij, N.A. Bajkov, M.V. Shcherbakov, E.E. Yashnov) [Oriental themes, images, motives in Russian literature of the Far East 
(B.M. Yulsky, N.A. Baikov, M.V. Shcherbakov, E.E. Yashnov)]. Vladivostok, Dal'nevost. federal. un-t, 2015, 276 p. (In Russian).

11. Kobzev N.A. Roman Aleksandra Grina (problematika, geroj, stil') [Alexander Grin's novel (problems, character, style)]. Kishinev, SHtiinca, 1983, 140 p. (In Russian).

12. Lotman YU.M. Kukly v sisteme kul'tury [Dolls in the culture system]. Izbrannye stat'i [Selected articles]. V. 1. Tallinn, Aleksandra, 1992, pp. 377-380. (In Russian).

13. Nabokov V.V. Lolita. Kamera obskura [Lolita. Pinhole camera]. Tomsk, Krasnoyarskij rabochij, 1991, 448 p. (In Russian). 14. Solnceva N.M. Reputaciya kukly [The reputation of a doll]. Moscow, Vodolej, 2017, 176 p. (In Russian).

15. Stepanyuk Yu.V. Rol' obraza beloj mazurki v kartine mira odnoimyonnoj povesti Borisa YUl'skogo [The role of the image of the white mazurka in the picture of the world of Boris Yulsky's tale of the same name]. Filologicheskie otkrytiya [Philological discoveries]. 2015, no. 3, pp. 181-184. (In Russian).

16. Strel'nikova L.Yu. Osnovnye tendencii russkoj i zapadnoevropejskoj literatury v kontekste mirovoj kul'tury: monografiya [The main trends of Russian and Western European literature in the context of world culture: monograph]. Armavir, RIO AGPA, 2013, 367 p. (In Russian).

17. Uskova T.F. Syuzhet o bludnom syne v rasskazah V. Nabokova "Zvonok" i B. Yul'skogo "Svyatochnyj gost" [The plot of the prodigal son in the stories by Nabokov's "Bell" and B. Yulsky's "Christmas Guest"]. Pamyat' i narrativ sbornik [Memory and narrative compilation]. 2012, pp. 148-152. (In Russian).

18. Fedyaj D. Statuya v edikule i maneken v vitrine: zhivoe, nezhivoe, ozhivayushchee [The statue in the edicula and the mannequin in the window: animate, inanimate, alive]. Istoricheskie, filosofskie, politicheskie i yuridicheskie nauki, kul'turologiya i iskusstvovedenie. Voprosy teorii i praktiki [Historical, philosophical, political and law sciences, cultural studies and art history. Questions of theory and practice]. 2015, no. 7 (57), in 2 p., p. 1, pp. 180-183. (In Russian).

19. Chayanov A.V. Moskovskaya gofmaniada [Moscow Hoffmanniad]. Moscow, Tonchu, 2006, 350 p. (In Russian).

20. Shchyogolev N.A. Pobednoe otchayan'e. Sobranie sochinenij [Victorious despair. Collected works]. Moscow, Vodolej, 2014, 352 p. (In Russian).

21. Yul'skij B. Zelenyj legion: povest' i rasskazy [The green legion: tales and stories]. Vladivostok, Al'manah "Rubezh", 2011, 560 p. (In Russian).

Received 04.04.2020

Kryukova M.I., Candidate of Philology, Junior Researcher

The Institute of Philology of SD RAS

Nikolaeva st., 8, Novosibirsk, Russia, 630090

E-mail: iamdaisy@mail.ru 